Prepared in cooperation with Camp Atterbury Joint Maneuver Training Center, Edinburgh, Indiana

\title{
Flood-Inundation Maps for the Driftwood River and Sugar Creek near Edinburgh, Indiana
}

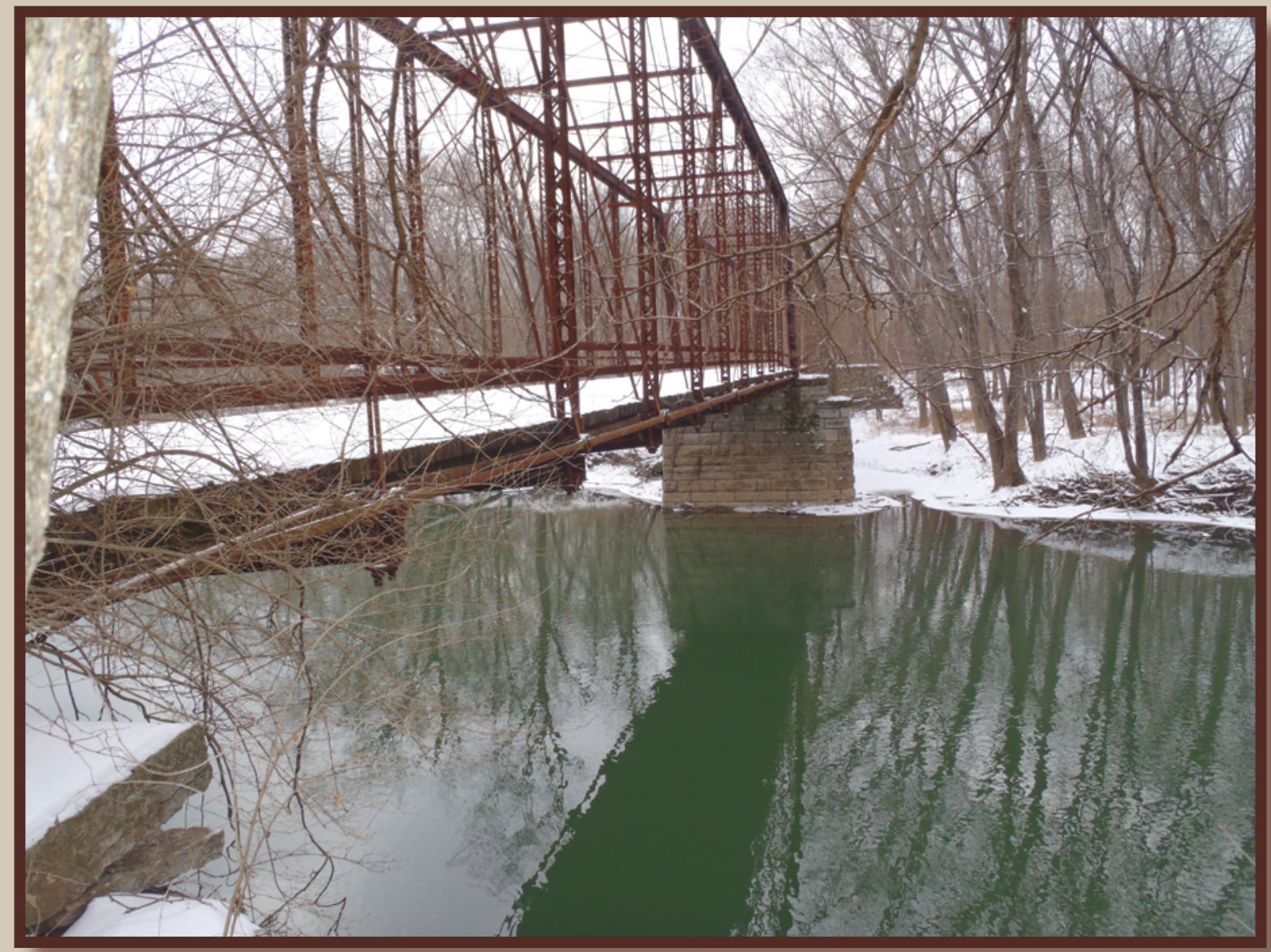

Pamphlet to accompany

Scientific Investigations Map 3210 
Cover. Hendricks Ford Bridge over the Driftwood River, near Edinburgh, Ind. (Photograph by Chad Menke, USGS, January 2011). 


\section{Flood-Inundation Maps for the Driftwood River and Sugar Creek near Edinburgh, Indiana}

By Kathleen K. Fowler, Moon H. Kim, and Chad D. Menke

Prepared in cooperation with Camp Atterbury Joint Maneuver Training Center, Edinburgh, Indiana

Pamphlet to accompany

Scientific Investigation Map 2012-3210 


\section{U.S. Department of the Interior \\ KEN SALAZAR, Secretary \\ U.S. Geological Survey \\ Marcia K. McNutt, Director}

\section{U.S. Geological Survey, Reston, Virginia: 2012}

For more information on the USGS - the Federal source for science about the Earth, its natural and living resources, natural hazards, and the environment, visit http://www.usgs.gov or call 1-888-ASK-USGS.

For an overview of USGS information products, including maps, imagery, and publications, visit http://www.usgs.gov/pubprod

To order this and other USGS information products, visit http://store.usgs.gov

Any use of trade, product, or firm names is for descriptive purposes only and does not imply endorsement by the U.S. Government.

Although this report is in the public domain, permission must be secured from the individual copyright owners to reproduce any copyrighted materials contained within this report.

Suggested citation:

Fowler, K.K., Kim, M.H., and Menke, C.D., 2012, Flood-inundation maps for the Driftwood River and Sugar Creek near Edinburgh, Indiana: U.S. Geological Survey Scientific Investigations Map 3210, 8 p. pamphlet, 9 sheets, scale 1:54,000. 


\section{Contents}

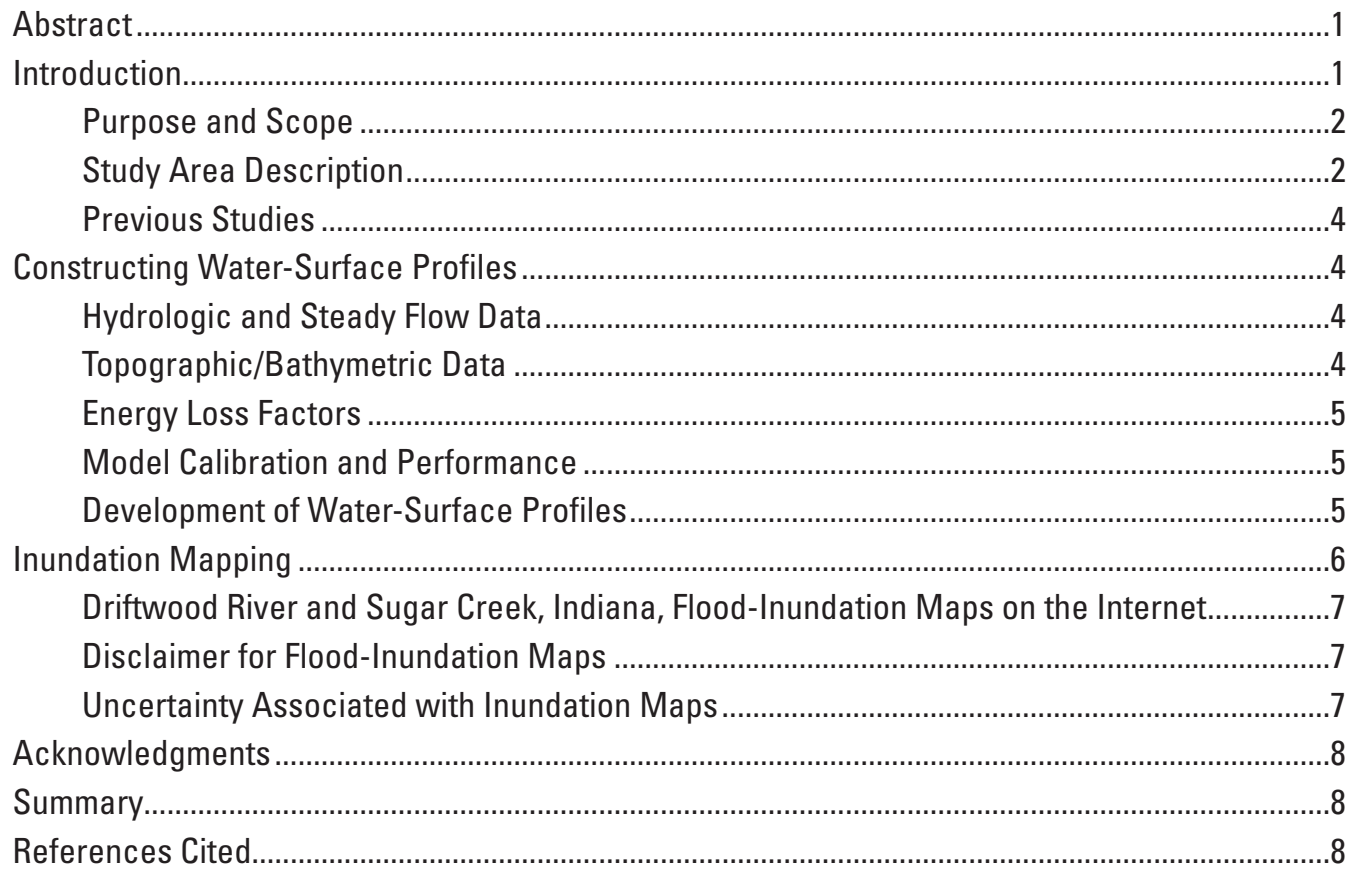

\section{Figure}

1. Location of study reaches for the Driftwood River and Sugar Creek, and location of USGS streamgage sites

\section{Tables}

1. USGS Streamgage information for sites near Edinburgh, Indiana.

2. Comparison of measured water-surface elevations at USGS streamgage 03363000 Driftwood River near Edinburgh, Indiana, with water-surface elevations output from the hydraulic model.

3. Comparison of measured water-surface elevations at USGS streamgage 03362500 Sugar Creek near Edinburgh, Indiana, with water-surface elevations output from the hydraulic model

4. Stages and water-surface elevations, in feet, with corresponding discharge estimates at selected locations for the Driftwood River near Edinburgh, Indiana, for simulated water-surface profiles.

5. Stages and water-surface elevations, in feet, with corresponding discharge estimates at selected locations for Sugar Creek near Edinburgh, Indiana, for simulated water-surface profiles. 


\section{Map Sheets}

1-9. Flood-inundation maps for Driftwood River and Sugar Creek near Edinburgh, Indiana, Corresponding to Varying Stages in Feet (noted below) and Varying Elevations in Feet (NAVD88) at the U.S. Geological Survey Streamgage 03363000

1. Stage of 9.00 and an elevation of 645.60 feet........................................................... link

2. Stage of 10.00 and an elevation of 646.60 feet......................................................... link

3. Stage of 11.00 and an elevation of 647.60 feet............................................................ link

4. Stage of 12.00 and an elevation of 648.60 feet........................................................... link

5. Stage of 13.00 and an elevation of 649.60 feet.......................................................... link

6. Stage of 14.00 and an elevation of 650.60 feet........................................................... link

7. Stage of 15.00 and an elevation of 651.60 feet......................................................... link

8. Stage of 16.00 and an elevation of 652.60 feet......................................................... link

9. Stage of 17.00 and an elevation of 653.60 feet...................................................... link 


\section{Conversion Factors}

Inch/Pound to SI

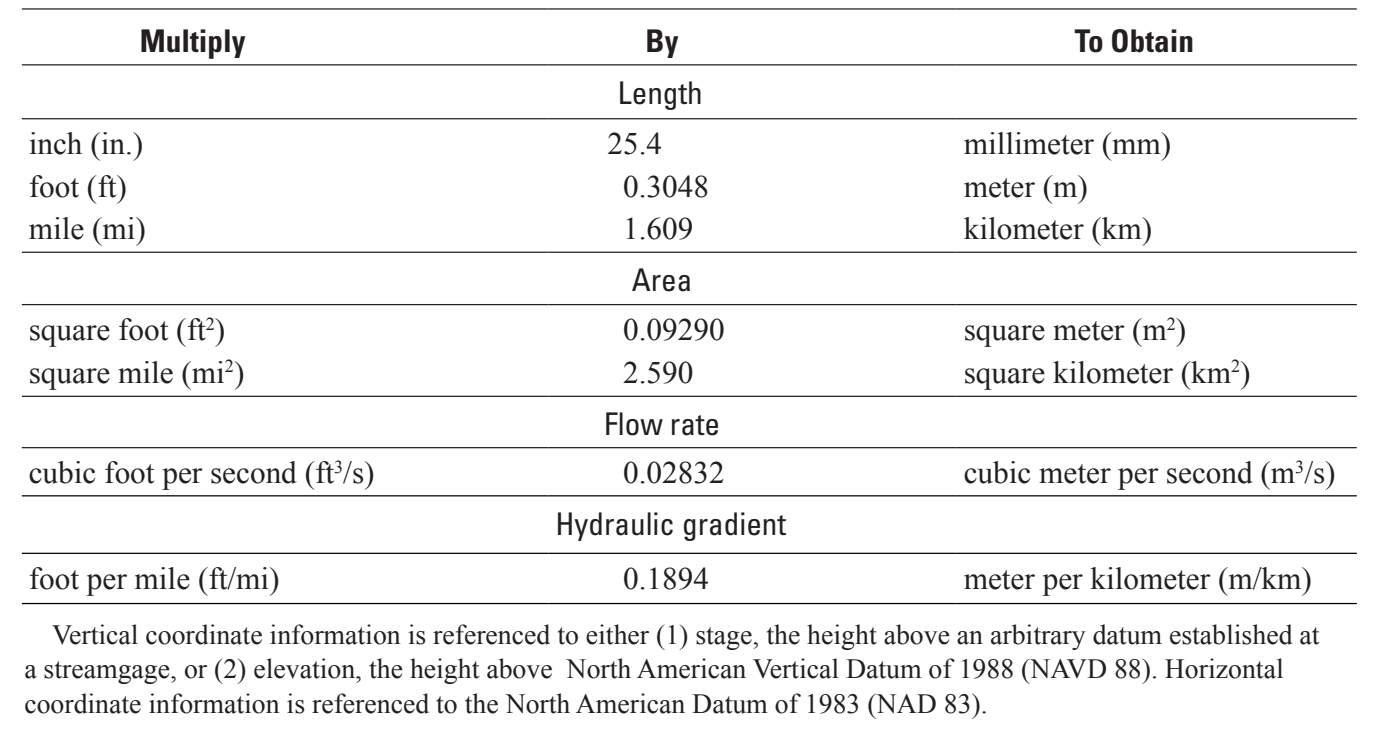





\title{
Flood-Inundation Maps for the Driftwood River and Sugar Creek near Edinburgh, Indiana
}

\author{
By Kathleen K. Fowler, Moon H. Kim, and Chad D. Menke
}

\section{Abstract}

Digital flood-inundation maps for an 11.2 mile reach of the Driftwood River and a 5.2 mile reach of Sugar Creek, both near Edinburgh, Indiana, were created by the U.S. Geological Survey (USGS) in cooperation with the Camp Atterbury Joint Maneuver Training Center, Edinburgh, Indiana. The inundation maps, which can be accessed through the USGS Flood Inundation Mapping Science Web site at http://water.usgs.gov/ osw/flood_inundation/, depict estimates of the areal extent of flooding corresponding to selected water levels (stages) at the USGS streamgage 03363000 Driftwood River near Edinburgh, Ind. Current conditions at the USGS streamgage in Indiana may be obtained on the Internet at http://waterdata.usgs.gov/ in/nwis/current/?type $=$ flow. In addition, the information has been provided to the National Weather Service (NWS) for incorporation into their Advanced Hydrologic Prediction Service (AHPS) flood warning system at http:/water.weather. gov/ahps/. The NWS forecasts flood hydrographs at many places that are often collocated at USGS streamgages. That forecasted peak-stage information, also available on the Internet, may be used in conjunction with the maps developed in this study to show predicted areas of flood inundation.

For this study, flood profiles were computed for the stream reaches by means of a one-dimensional step-backwater model. The model was calibrated using the most current stage-discharge relations at the USGS streamgage 03363000 Driftwood River near Edinburgh, Ind. The hydraulic model was then used to determine elevations throughout the study reaches for nine water-surface profiles for flood stages at $1-\mathrm{ft}$ intervals referenced to the streamgage datum and ranging from bankfull to nearly the highest recorded water level at the USGS streamgage 03363000 Driftwood River near Edinburgh, Ind. The simulated water-surface profiles were then combined with a geospatial digital elevation model (derived from Light Detection and Ranging (LiDAR) data) in order to delineate the area flooded at each water level.

The availability of these maps along with real-time information available online regarding current stage from USGS streamgages and forecasted stream stages from the NWS provide emergency management personnel and residents with information that is critical for flood response activities such as evacuations and road closures as well as for post flood recovery efforts.

\section{Introduction}

The Camp Atterbury Joint Training and Maneuvers Center, hereafter known as Camp Atterbury, is the home base for members of the Army National Guard and Army Reserves, Marine Corps, and other units that train and mobilize at Camp Atterbury. Camp Atterbury also serves as a training site for both individuals and units from all branches of service for both Reserve and Active Duty training and other special training events. In recent years Camp Atterbury has mobilized over 50,000 and demobilized over 30,000 soldiers, sailors, and airmen for duty in the United States and overseas. The facility has live fire ranges along with more than 33,000 acres of maneuver training area and dozens of artillery and mortar firing points (http://www.campatterbury.in.ng.mil/AboutUs/ tabid/691/Default.aspx, accessed Oct. 21, 2011).

Camp Atterbury has a varying population depending on military activities at any particular time. The area has undergone flooding numerous times; most notably in 2008. The majority of flood damages have occurred along the Driftwood River, Sugar Creek, and a tributary to the Driftwood River, Nineveh Creek. Flood plains along the study reach are moderately developed and contain a mix of military, residential, agricultural, and forested areas. The town closest to Camp Atterbury is Edinburgh, Indiana, with a population of approximately 4,480 people in the 2010 census (U.S. Census Bureau, 2010).

Prior to this study, Camp Atterbury officials have relied on several information sources to make decisions on how to best alert the public and military personnel and to mitigate flood damages. One source is the Federal Emergency Management Agency (FEMA) Flood Insurance Study (FIS) for both Bartholomew and Johnson Counties dated September 15, 1981, and August 2, 2007 respectively (Federal Emergency Management Agency, 1981, 2007). A second source of information is the USGS streamgage 03362500 Sugar Creek near Edinburgh, Ind., from which current or historical water levels (stage) can be obtained at http://waterdata.usgs.gov/in/nwis/ current/?type $=$ flow. A third source is the National Weather Service's forecast of peak stage at the USGS streamgages through the AHPS site at http://water.weather.gov/ahps2/ index.php? wfo=ind. Although USGS current stage and NWS information is useful for residents in the immediate vicinity of a streamgage, it is of limited use to residents farther upstream 
or downstream because the water-surface elevation is not constant along the entire stream channel. Also, FEMA and State emergency management mitigation teams or property owners typically lack information related to how deep the water is at locations other than near USGS streamgages or NWS floodforecast points.

\section{Purpose and Scope}

The purpose of this report is to describe the development of a series of estimated flood-inundation maps for the Driftwood River and Sugar Creek near Camp Atterbury, Edinburgh, Indiana, and to make these maps available to emergency workers and the public on the USGS Flood Inundation Mapping Science Web site available at http://water.usgs.gov/osw/ flood_inundation/. The purpose is to (1) provide users with a library of flood-inundation maps that correspond to a range of flood elevations on rivers near Camp Atterbury, and (2) provide links between NWS forecasted peak stage at streamgages during times of flood and the corresponding flood-inundation map that shows what that forecast stage will look like on the ground.

The scope of the study was limited to approximately 11.2 miles (mi) of the Driftwood River, $5.2 \mathrm{mi}$ of Sugar Creek, and $1.1 \mathrm{mi}$ of the Big Blue River for a total of $17.5 \mathrm{mi}$. The upstream extent of the Driftwood River begins at the confluence of Sugar Creek and the Big Blue River and ends at a location about $0.6 \mathrm{mi}$ downstream of W. Lowell Road. The upstream extent of Sugar Creek begins at a location about 0.5 mi upstream of the U.S. Government Railroad Bridge and ends at its confluence with Big Blue and Driftwood River. The short reach of the Big Blue River begins at the U.S. Highway 31 Bridge down to the confluence with Sugar Creek and was included for modeling and mapping continuity (fig. 1).

Development of the inundation maps was accomplished by first constructing water-surface profiles for the study reach. Constructing water-surface profiles included (1) re-establishment of the streamgage on the Driftwood River and examination of current and historical data from streamgages on the Driftwood River and Sugar Creek (table 1); (2) collection of hydrologic and steady flow data; (3) collection of topographic, geometric (for structures/bridges), and bathymetric data throughout the study reach; (4) determination of energy-loss factors (roughness coefficients) in the stream channel and flood plain; (5) model calibration and evaluation and (6) computation of water-surface profiles using the U.S. Army Corps of Engineer's HEC-RAS computer program (U.S. Army Corps of Engineers, 2010).

Flood-inundation maps were then produced from the results of the modeled water-surface profiles. Production of estimated flood-inundation maps corresponding to targeted water-surface elevations at the gages was done using the U.S. Army Corps of Engineer's HEC-GeoRas computer program (U.S. Army Corps of Engineers, 2009) and a Geographic Information System (GIS). An interface tool that links to USGS real-time streamgage information and (or) NWS forecasted peak stage to facilitate the online display of userselected flood-inundation maps was developed.

Techniques that varied significantly from previously documented methods due to local hydrologic conditions or available data are described in detail in this report. Maps were produced for inundation levels referenced to the stage at the USGS streamgage 03363000 Driftwood River near Edinburgh, Ind., and range from approximately bankfull to near the maximum recorded water level at the gage site.

\section{Study Area Description}

The Driftwood River, and those portions of Sugar Creek and Big Blue River that are included in this study, are in south central Indiana near the northern tip of the Scottsburg Lowland physiographic division. The USGS streamgage 03363000 Driftwood River near Edinburgh, Ind., hereafter referred to as the Driftwood River gage, is in Bartholomew County and the USGS streamgage 03362500 on Sugar Creek near Edinburgh, Ind., hereafter referred to as the Sugar Creek gage, is in Johnson County. The Driftwood River is one of the shortest rivers in Indiana with a length of 16 miles. The Driftwood River originates in the southernmost part of Johnson County, and flows generally southward before flowing into the East Fork White River in Columbus, Ind. There are two major tributaries to the Driftwood River that join the main stem as it flows along the boundary of Camp Atterbury: Nineveh Creek and Muddy Branch Creek. The basin terrain is generally broad terraced valleys and low till-covered hills. The drainage area of the Driftwood River study reach ranges from 1,058 square miles $\left(\mathrm{mi}^{2}\right)$ at the upstream end (the confluence of Sugar Creek and Big Blue River) to $1,137 \mathrm{mi}^{2}$ at the downstream extent of the study reach. The Driftwood River reach is approximately $11.2 \mathrm{mi}$ long, has an average top-of-bank channel width of about 220 feet (ft) and an average channel slope of 2.5 feet per mile (ft/mi). The Driftwood River winds through farmlands with wooded areas along both banks. The upper reach is mostly natural while the lower reach shows some development. The main channel within the study reach has three major road crossings: Hendricks Ford Road, Tannehill Road, and West Lowell Road.

Sugar Creek originates in Henry County and the river flows generally southward before joining the Big Blue River to form the Driftwood River. The drainage area of the Sugar Creek study reach ranges from $468 \mathrm{mi}^{2}$ at the upstream extent to $474 \mathrm{mi}^{2}$ at the downstream extent. This part of the study reach is about $5.2 \mathrm{mi}$. in length and is entirely in Johnson County. In the study area, Sugar Creek has an average top-ofbank channel width of about $160 \mathrm{ft}$ and an average channel slope of $3.5 \mathrm{ft} / \mathrm{mi}$. Near the Camp Atterbury property, Sugar Creek flows through mostly forested lowlands and undeveloped gently rolling terrain. The channel has two major road crossings, County Road 650 South and Hospital Road, and a U.S. Government railroad crossing. 


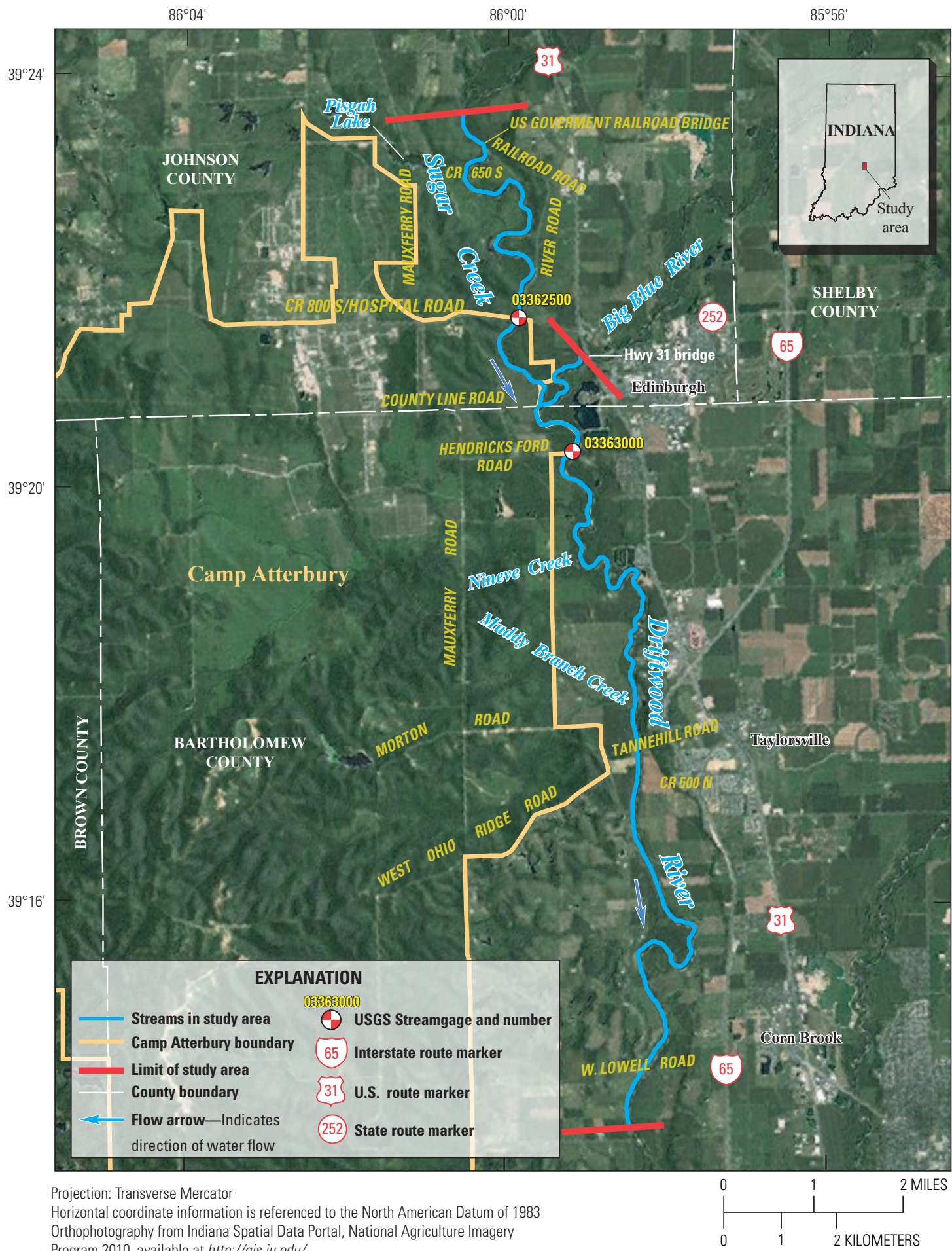

Orthophotography from Indiana Spatial Data Portal, National Agriculture Imagery

Program 2010, available at $h$ ttp://gis.iu.edu/

Figure 1. Location of study reaches for the Driftwood River and Sugar Creek, and location of USGS streamgages. 
Table 1. USGS Streamgage information for sites near Edinburgh, Indiana.

\begin{tabular}{|c|c|c|c|c|c|c|c|}
\hline $\begin{array}{c}\text { Steamgage } \\
\text { name }\end{array}$ & $\begin{array}{c}\text { Streamgage } \\
\text { number }\end{array}$ & $\begin{array}{l}\text { Drainage } \\
\text { area } \\
\left(\mathrm{mi}^{2}\right)\end{array}$ & $\begin{array}{l}\text { Latitude } \\
\text { (NAD27) }\end{array}$ & $\begin{array}{l}\text { Longitude } \\
\text { (NAD27) }\end{array}$ & Period of record & $\begin{array}{c}\text { Datum } \\
\text { of gage } \\
\text { (NAVD88) }\end{array}$ & $\begin{array}{l}\text { Maximum recorded } \\
\text { flood elevation } \\
\text { (NAVD88) } \\
\text { and date }\end{array}$ \\
\hline
\end{tabular}

\section{Previous Studies}

A Flood Insurance Study (FIS) for Bartholomew County (Federal Emergency Management Agency, 1981) was completed by the Louisville District of the U.S. Army Corps of Engineers for the Federal Insurance Administration in August, 1979. That study provided information on the $0.2,1.0,2.0$, and 10 percent annual exceedance probability water-surface profiles and associated flood plain maps for the Driftwood River, East Fork White River, Flatrock River, and numerous creeks and tributaries. A revised FIS was completed for Johnson County in 2007 (Federal Emergency Management Agency, 2007). That study provided information on the $0.2,1.0,2.0$, and 10 percent annual exceedance probability water-surface profiles and associated flood plain maps for Sugar Creek, Big Blue River, and numerous creeks, ditches, and swales in Johnson County.

\section{Constructing Water-Surface Profiles}

The water-surface profiles used to produce the nine flood-inundation maps in this study were computed using HEC-RAS, version 4.1.0 (U.S. Army Corps of Engineers, 2010). HEC-RAS is a one-dimensional step-backwater model for simulation of water-surface profiles with steady-state (gradually varied) or unsteady-state flow computation options. The HEC-RAS analysis for this study was done using the steady-state flow computation option.

\section{Hydrologic and Steady Flow Data}

The study area hydrologic network consists of two streamgages (fig. 1; table 1). One of the gages, Sugar Creek, already existed; the other gage at Driftwood River had been discontinued in 1991 and was re-activated in 2011 with a continuous recorder and recording tipping-bucket rain gage. Water level (stage) is measured continuously at both of the sites. All water-surface elevations are referenced to North American Vertical Datum of 1988 (NAVD 88). The gages are equipped with satellite radio transmitters that allow data to be transmitted routinely on the Internet within an hour of collection. Data can be accessed at http://waterdata.usgs.gov/in/nwis/ current/?type $=$ flow by clicking on the appropriate streamgage number.

Steady-flow data consisted of flow regime, boundary conditions (either known water-surface elevation associated with a previous study, normal depth, or streamgage rating curve value), and peak discharge information.

\section{Topographic/Bathymetric Data}

Channel cross sections were developed from USGS field surveys that were carried out in May of 2011. These cross sections provide detailed channel elevation data below the water surface and were collected using hydroacoustic instrumentation to measure depth and Differential Global Positioning System (DGPS) instrumentation to determine horizontal position. Light Detection and Ranging (LiDAR) data were used to provide digital elevation data for the portions of the cross sections that were above the water surface at the time of the surveys. Two sets of LiDAR data were merged for this study. The LiDAR data for Camp Atterbury and Sugar Creek were originated by Indianapolis Mapping and Geographic Infrastructure System in 2010 (Greater Indianapolis Area Aerial Lidar Survey, 2010). The LiDAR data for the Driftwood River were originated from Aero-Metric, Inc., Sheboygan, Wisconsin, in 2010 .

Various manmade drainage structures (bridges and roadway embankments) in and along the stream affect or have the potential to affect water-surface elevations during floods along the stream. To properly account for these features in the model, structural dimensions for six bridges were measured and surveyed in the field concurrently with the stream channel surveys. A detailed description of the methods used to acquire and process the topographic and bathymetric data can be found in Bales and others (2007). 


\section{Energy Loss Factors}

Field observations and high-resolution aerial photographs were used to select initial (pre-calibration) Manning's roughness coefficients (" $n$ " values) for energy (friction) loss calculations. The initial values were adjusted as part of the calibration process. The $n$-values for the main channel of the Driftwood River range from 0.035 to 0.044 , and $n$-values for overbanks range from 0.045 to 0.12 . For the main channel of Sugar Creek, $n$-values range from 0.031 to 0.035 and $n$-values for the overbanks range from 0.08 to 0.10 . The $n$-value for the main channel of the Big Blue River was 0.038, and $n$-values for overbanks range from 0.08 to 0.09 .

\section{Model Calibration and Performance}

The hydraulic model was calibrated to the stage-discharge relations at the USGS streamgage 03363000 Driftwood River near Edinburgh, Ind., and verified by comparing the stage values at the USGS streamgage 03362500 Sugar Creek near Edinburgh, Ind., based on estimated streamflow. Model calibration was accomplished by adjusting Manning's $n$-values and loss coefficients until the results of the hydraulic computations closely agreed with the known water stage values. Differences between measured and simulated water-surface elevations were less than $0.16 \mathrm{ft}$ for the Driftwood River gage (table 2). The differences between estimated and simulated water-surface elevations for the Sugar Creek gage were less than $0.25 \mathrm{ft}$ (table 3 ). The results demonstrate that the model is capable of simulating accurate water levels over a wide range of flows in the basin. However, due to the relatively large distance from the Driftwood River gage to the downstream extent of the study (10.3 mi), the accuracy of the maps may decrease toward the downstream end. No high-water marks were used for model validation since the marks from the 2008 flood were at a higher elevation than the highest profile used in the model. Details on techniques used in model development and calibration can be found in Bales and others (2007).

Table 2. Comparison of measured water-surface elevations at USGS streamgage 03363000 Driftwood River near Edinburgh, Indiana, with water-surface elevations output from the hydraulic model.

\begin{tabular}{rccc}
\hline $\begin{array}{c}\text { Stage } \\
\text { (ft) }\end{array}$ & $\begin{array}{c}\text { Measured water- } \\
\text { surface elevation } \\
\text { (ft, NAVD88) }\end{array}$ & $\begin{array}{c}\text { Modeled water- } \\
\text { surface elevation } \\
\text { (ft, NAVD88) }\end{array}$ & $\begin{array}{c}\text { Elevation } \\
\text { difference } \\
\text { (ft) }\end{array}$ \\
\hline 9.00 & 645.60 & 645.51 & 0.09 \\
10.00 & 646.60 & 646.60 & 0.00 \\
11.00 & 647.60 & 647.47 & 0.13 \\
12.00 & 648.60 & 648.59 & 0.01 \\
13.00 & 649.60 & 649.54 & 0.06 \\
14.00 & 650.60 & 650.45 & 0.15 \\
15.00 & 651.60 & 651.48 & 0.12 \\
16.00 & 652.60 & 652.73 & -0.13 \\
17.00 & 653.60 & 653.75 & -0.15 \\
\hline
\end{tabular}

Table 3. Comparison of measured water-surface elevations at USGS streamgage 03362500 Sugar Creek near Edinburgh, Indiana, with water-surface elevations output from the hydraulic model.

\begin{tabular}{cccc}
\hline $\begin{array}{c}\text { Stage } \\
\text { (ft) }\end{array}$ & $\begin{array}{c}\text { Measured water- } \\
\text { surface elevation } \\
\text { (ft, NAVD88) }\end{array}$ & $\begin{array}{c}\text { Modeled water- } \\
\text { surface elevation } \\
\text { (ft, NAVD88) }\end{array}$ & $\begin{array}{c}\text { Elevation } \\
\text { difference } \\
\text { (ft) }\end{array}$ \\
\hline 7.62 & 653.45 & 653.40 & 0.05 \\
8.19 & 654.02 & 654.03 & -0.01 \\
8.79 & 654.62 & 654.68 & -0.06 \\
9.65 & 655.48 & 655.64 & -0.16 \\
10.59 & 656.42 & 656.66 & -0.24 \\
11.70 & 657.53 & 657.48 & 0.05 \\
13.10 & 658.93 & 658.85 & 0.08 \\
15.03 & 660.86 & 660.65 & 0.21 \\
16.42 & 662.25 & 662.36 & -0.11 \\
\hline
\end{tabular}

\section{Development of Water-Surface Profiles}

Profiles were developed for a total of nine stages at 1-ft intervals between $9.00 \mathrm{ft}$ and $17.00 \mathrm{ft}$ as referenced to the USGS streamgage 03363000 Driftwood River near Edinburgh, Ind., corresponding to elevations of between 645.60 and $653.60 \mathrm{ft}$ NAVD88.

Models on the Driftwood River were calibrated to produce the selected profile elevations at the USGS streamgage 03363000 (table 4) and the estimated profile elevations at the Sugar Creek gage (table 5). Discharges at the mouth of Nineveh Creek and Muddy Branch Creek, tributaries to the Driftwood River, were determined by calculating cubic feet per second per square mile (CFSM) that corresponded to the measured discharges at the Driftwood River gage. Discharges at the Pisgah Lake tributary and at the upstream extent of Sugar Creek were also determined using CFSM. The CFSM is defined as the average number of cubic feet of water per second flowing from each square mile of area drained by a stream, assuming that the runoff is distributed uniformly in time and area.

Discharges on Sugar Creek and Big Blue River at the confluence with the Driftwood River were determined by calculating the relative percentage of drainage area to the combined drainage area of the Driftwood River at the gage. The drainage area for Sugar Creek is approximately 45 percent of the drainage area at the Driftwood River gage. The drainage area for Big Blue River is approximately 55 percent of the drainage area at the Driftwood River gage. It is important to note that the percentages of the two contributing basins is an estimate based on drainage areas, the actual discharge contributions depend on precipitation amounts in each basin. If a large amount of precipitation falls in only one of the contributing basins, the percentage of flow to the Driftwood River increases from that basin. Conversely, if little or no precipitation occurs in one of the basins there is little contribution to Driftwood River and the percentage decreases. Drainage areas 
Table 4. Stages and water-surface elevations, in feet, with corresponding discharge estimates at selected locations for the Driftwood River near Edinburgh, Indiana, for simulated water-surface profiles.

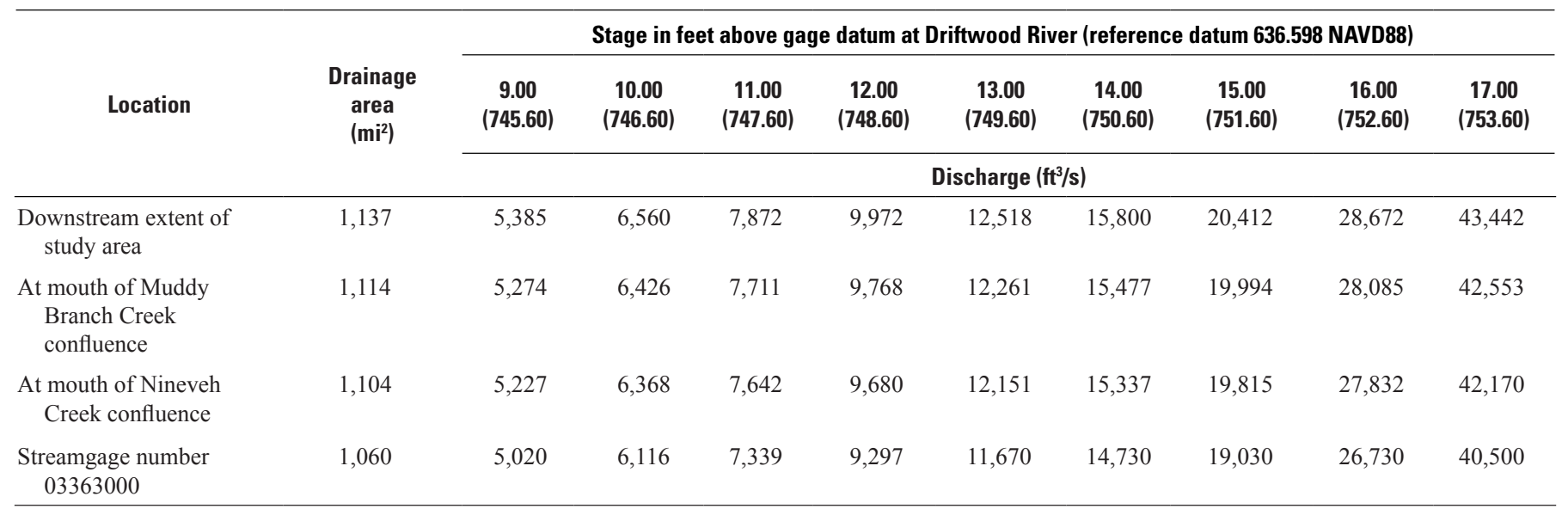

Table 5. Stages and water-surface elevations, in feet, with corresponding discharge estimates at selected locations for Sugar Creek near Edinburgh, Indiana, for simulated water-surface profiles.

\begin{tabular}{|c|c|c|c|c|c|c|c|c|c|c|}
\hline \multirow{3}{*}{ Location } & \multirow{3}{*}{$\begin{array}{c}\text { Drainage } \\
\text { area } \\
\left(\mathrm{mi}^{2}\right)\end{array}$} & \multicolumn{9}{|c|}{ Stage in feet above gage datum at Driftwood River (reference datum 636.598 NAVD88) } \\
\hline & & $\begin{array}{c}7.60 \\
(653.40)\end{array}$ & $\begin{array}{c}8.20 \\
(654.00)\end{array}$ & $\begin{array}{c}8.80 \\
(654.60)\end{array}$ & $\begin{array}{c}9.60 \\
(655.50)\end{array}$ & $\begin{array}{c}10.60 \\
(656.40)\end{array}$ & $\begin{array}{c}11.70 \\
(657.50)\end{array}$ & $\begin{array}{c}13.10 \\
(658.90)\end{array}$ & $\begin{array}{c}15.00 \\
(660.90)\end{array}$ & $\begin{array}{c}16.40 \\
(662.20)\end{array}$ \\
\hline & & \multicolumn{9}{|c|}{ Discharge $\left(\mathrm{ft}^{3} / \mathrm{s}\right)$} \\
\hline $\begin{array}{l}\text { Streamgage number } \\
\quad 03362500\end{array}$ & 474.2 & 2,259 & 2,752 & 3,303 & 4,184 & 5,251 & 6,628 & 8,564 & 12,028 & 18,225 \\
\hline $\begin{array}{l}\text { Upstream extent of study } \\
\text { area }\end{array}$ & 459.2 & 2,188 & 2,666 & 3,199 & 4,052 & 5,086 & 6,420 & 8,294 & 11,650 & 17,652 \\
\hline
\end{tabular}

were calculated using a Web-based GIS application called Streamstats which can be accessed at http://water.usgs.gov/ osw/streamstats/indiana.html. Profile verification at the Sugar Creek gage used elevations that corresponded to 45 percent of the discharges at the Driftwood River gage. For example, the $9.00 \mathrm{ft}$ profile at the Driftwood River gage has a discharge of 5,020 cubic feet per second $\left(\mathrm{ft}^{3} / \mathrm{s}\right)$. Forty-five percent of 5,020 $\mathrm{ft}^{3} / \mathrm{s}$ is $2,259 \mathrm{ft}^{3} / \mathrm{s}$. Using the current stage-discharge rating for the Sugar Creek gage, a discharge of $2,259 \mathrm{ft}^{3} / \mathrm{s}$ corresponds to a stage of 7.62 or an elevation of $653.45 \mathrm{ft}$. This comparison method was used for each of the nine profiles. The modeled elevations at the Driftwood River gage were all within 0.16 $\mathrm{ft}$ of the elevations corresponding to the estimated discharges at the gage. The modeled elevations at the Sugar Creek gage were all within $0.25 \mathrm{ft}$ of the elevations corresponding to the estimated discharges at the gage.

\section{Inundation Mapping}

Flood-inundation maps were created for two stream reaches near USGS streamgages, one of which, the Driftwood River gage, has been designated as a NWS flood-forecast point (as of 2012). The maps were created in a GIS by combining the water-surface profiles and digital elevation model data. The digital elevation model (DEM) data were derived from merged LiDAR data sets with horizontal accuracy ranging from 1.0 to $3.2 \mathrm{ft}$ and a vertical accuracy ranging from 0.18 to $0.37 \mathrm{ft}$. The initial resolution of the DEM with 2.5 - $\mathrm{ft}$ cell size was later modified to $10-\mathrm{ft}$ cell size in order to reduce the GIS processing time. Estimated flood-inundation boundaries for each simulated profile were developed with HECGeoRAS software (U.S. Army Corps of Engineers, 2009). 
HEC-GeoRAS is a set of procedures, tools, and utilities for processing geospatial data in ArcGIS by using a graphical user interface (Whitehead and Ostheimer, 2009). The interface allows the preparation of geometric data for import into HEC-RAS and processes simulation results exported from HEC-RAS (U.S. Army Corps of Engineers, 2010). The HECGeoRAS results at the cross sections were adjusted to ensure a hydraulically reasonable transition of the boundary between modeled cross sections relative to the contour data for the land surface (Whitehead and Ostheimer, 2009). The maps show estimated flood-inundated areas overlaid on high-resolution, geo-referenced aerial photographs of the study area for each of the water-surface profiles that were generated by the hydraulic model.

\section{Driftwood River and Sugar Creek, Indiana, Flood-Inundation Maps on the Internet}

The flood-inundation maps and current study documentation are available online at the U.S. Geological Survey Publications Warehouse (http://pubs.usgs.gov/sim/2012/3210). Also, a Flood Inundation Mapping Science website has been established to provide a portal for USGS flood-inundation study information to the public at http://water.usgs.gov/osw/ flood_inundation/. That web portal has a link (http://wim. usgs.gov/FIMI/FloodInundationMapper.html) to interactive online map libraries that can be downloaded in several commonly-used electronic file formats. In the latter link, each stream reach displayed contains further links to NWISWeb graphs of the current stage and streamflow at USGS streamgage 03363000 to which the inundation maps are referenced. A link also is provided to the NWS Advanced Hydrologic Prediction Service (AHPS) site (http:/water.weather.gov/ ahps/) so that the user can obtain applicable information on forecasted peak stage. The estimated flood-inundation maps are displayed in sufficient detail to note the extent of flooding with respect to individual structures so that preparations for flooding and decisions for emergency response can be performed efficiently. Roadways and bridges were closely reviewed and are shown as shaded (inundated and likely impassable) or not shaded (dry and passable) to facilitate emergency planning and use. However, buildings which are shaded do not reflect inundation but denote that bare earth surfaces in the vicinity of the buildings are inundated. When the water depth (as indicated in the Web Mapping Application by holding the cursor over an inundated area) in the vicinity of the building of interest exceeds that building's height, the structure can be considered fully submerged.

\section{Disclaimer for Flood-Inundation Maps}

Inundated areas shown should not be used for navigation, regulatory, permitting, or other legal purposes. The USGS provides these maps "as-is" for a quick reference, emergency planning tool but assumes no legal liability or responsibility resulting from the use of this information.

\section{Uncertainty Associated with Inundation Maps}

Although the flood-inundation maps represent the boundaries of inundated areas with a distinct line, some uncertainty is associated with these maps. The flood boundaries shown were estimated based on water stages and streamflows at selected USGS streamgages. Water-surface elevations along the stream reaches were estimated by steady-state hydraulic modeling, assuming unobstructed flow, and using discharges and hydrologic conditions anticipated at the USGS streamgage(s). The hydraulic model reflects the land-cover characteristics and any bridge, dam, levee, or other hydraulic structures existing as of September 2011. Unique meteorological factors (timing and distribution of precipitation) may cause actual discharges along the modeled reach to vary from assumed during a flood, which may lead to deviations in the water-surface elevations and inundation boundaries shown. Additional areas may be flooded due to unanticipated conditions such as: changes in the streambed elevation or roughness, backwater into major tributaries along a main stem river, or backwater from localized debris or ice jams. The accuracy of the floodwater extent portrayed on these maps will vary with the accuracy of the digital elevation model used to simulate the land surface. Additional uncertainties and limitations pertinent to this study may be described elsewhere in this report.

If this series of flood-inundation maps will be used in conjunction with National Weather Service (NWS) river forecasts, the user should be aware of additional uncertainties that may be inherent or factored into NWS forecast procedures. The NWS uses forecast models to estimate the quantity and timing of water flowing through selected stream reaches in the United States. These forecast models (1) estimate the amount of runoff generated by precipitation or snowmelt, (2) simulate the movement of floodwater as it proceeds downstream, and (3) predict the flow and stage (water-surface elevation) for the stream at a given location (AHPS forecast point) throughout the forecast period (every 6 hours and 3 to 5 days out in many locations). For more information on AHPS forecasts, please see: http://water.weather.gov/ahps/pcpn_and_river_ forecasting.pdf. 


\section{Acknowledgments}

The authors wish to thank the State and Federal agencies that have cooperated in the funding for the operation and maintenance of the gages used for this study, especially Camp Atterbury Joint Maneuver Training Center, Edinburgh, Indiana, the Indiana Department of Transportation, and the National Weather Service.

\section{Summary}

A series of estimated flood-inundation maps were developed in cooperation with Camp Atterbury Joint Maneuver Training Center for the Driftwood River and Sugar Creek near Edinburgh, Indiana. In addition to maps showing areas of inundation, downloadable GIS raster files and KML map files showing the depth of flooded areas were produced. The estimated inundation areas are shaded to give a general indication of depth of water at any point.

These maps, available at a USGS Web portal, in conjunction with the real-time stage data from the USGS streamgage 03363000 Driftwood River near Edinburgh, Ind., and National Weather Service flood-stage forecasts, can help to guide the general public in taking individual safety precautions and can provide Camp Atterbury officials with a tool to efficiently manage emergency flood operations and flood mitigation efforts.

The maps were developed using the U.S. Army Corps of Engineers' HEC-RAS and HEC-GeoRAS programs to compute water-surface profiles and to delineate estimated floodinundation areas for selected stream stages. The maps show estimated (shaded) flood-inundation areas overlaid on highresolution, geo-referenced, aerial photographs of the study area for stream stages between 9.00 and $17.00 \mathrm{ft}$ (645.60 and $653.60 \mathrm{ft}$ NAVD88) at USGS streamgage 03363000 Driftwood River near Edinburgh, Ind.

\section{References Cited}

Aero-Metric, Inc., 2010, Indiana Flood LiDAR (ARRA) Task Order, Remote-sensing Image: Sheboygan, Wis., AeroMetric, Inc.

Bales, J.D., Wagner, C.R., Tighe, K.C., and Terziotti, Silvia, 2007, LiDAR-derived flood-inundation maps for realtime flood-mapping applications, Tar River Basin, North Carolina: U.S. Geological Survey Scientific Investigations Report 2007-5032, 42 p.

Federal Emergency Management Agency (FEMA), 1981, Flood Insurance Study, County of Bartholomew, Indiana, Community Number 180006. Washington, D.C., 68 p.
Federal Emergency Management Agency (FEMA), 2007, Flood Insurance Study, Johnson County, Indiana, Flood Insurance Study Number 18081CV000A. Washington D.C., 140 p.

Greater Indianapolis Area Aerial Lidar Survey, 2010, Remotesensing Image: Indianapolis Metropolitan Planning Organization (IndyMPO), Indianapolis Mapping and Geographic Infrastructure System (IMAGIS).

U.S. Army Corps of Engineers, 2009, HEC-GeoRAS, GIS tools for support of HEC-RAS using ArcGIS, user's manual: U.S. Army Corps of Engineers, Hydrologic Engineering Center [variously paged]. Available at http://www.hec.usace. army.mil/software/hec-ras/hec-georas_downloads.html

U.S. Army Corps of Engineers, 2010, HEC-RAS river analysis system, hydraulic reference manual, version 4.1: U.S. Army Corps of Engineers, Hydrologic Engineering Center [variously paged]. Availabe at http://www.hec.usace.army. mil/software/hec-ras/hecras-download.html

U.S. Census Bureau, 2010, 2010 Census interactive population search IN-Edinburgh town: Washington, D.C., U.S. Census Bureau. Available at http://2010.census.gov/2010census/ popmap/ipmtext.php? $f=18: 1820404$

Whitehead, M.T., and Ostheimer, C.J., 2009, Development of a flood-warning system and flood-inundation mapping for the Blanchard River in Findlay, Ohio: U.S. Geological Survey Scientific Investigations Report 2008-5234, 9 p.

Publishing support provided by:

Denver Publishing Service Center

Manuscript approved for publication May 1, 2012

For more information concerning this publication, contact:

Director, Indiana Water Science Center

U.S. Geological Survey

5957 Lakeside Blvd.

Indianapolis, IN 46278

(317) 290-3333

Or visit the Indiana Water Science Center Web site at:

http://in.water.usgs.gov/

This report is available at: $h$ ttp://pubs.usgs.gov/sim/3210/. 


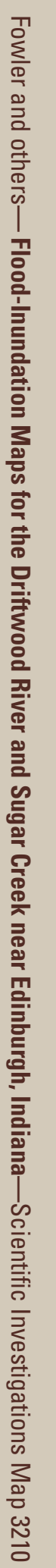

